\title{
Arsenic and Mercury Concentrations at Several Geothermal Systems in West Java, Indonesia
}

\author{
N.R. Herdianita ${ }^{1, *} \&$ B. Priadi ${ }^{2}$ \\ ${ }^{1}$ Research Group on Applied Geology, Faculty of Earth Science and Mineral \\ Technology - FIKTM, Institute of Technology Bandung (ITB), \\ Jalan Ganesa 10 Bandung 40125 - Indonesia, \\ Phone/Fax: 62-22-2502197, Email: herdianita@gc.itb.ac.id \\ ${ }^{2}$ Research Group on Geology and Paleontology, Faculty of Earth Science and Mineral \\ Technology - FIKTM, Institute of Technology Bandung (ITB), \\ Jalan Ganesa 10 Bandung 40125 - Indonesia, \\ Phone/Fax: 62-22-2502197, Email: bpriadi@gc.itb.ac.id
}

\begin{abstract}
A study at several geothermal systems in West Java, Indonesia shows that thermal waters could naturally contain up to $2.6 \mathrm{ppm}$ As and $6.5 \mathrm{ppb} \mathrm{Hg}$, and the surface hydrothermal alteration could contribute up to $50 \mathrm{ppm}$ As and $800 \mathrm{ppb} \mathrm{Hg}$. The higher the chloride content, the higher the contents of As and $\mathrm{Hg}$ of thermal waters. The amounts of As and $\mathrm{Hg}$ in an active geothermal system are influenced by the type of host rock, boiling and mixing processes, and adsorption of vapor and volcanic gases into thermal waters.
\end{abstract}

Keywords: active geothermal system; arsenic; contaminant; epithermal system; mercury; surface alteration.

\section{$1 \quad$ Introduction}

Recently, the contents of arsenic (As) and mercury (Hg) in geothermal areas were determined during an exploration survey. As and $\mathrm{Hg}$ occur in geothermal waters and are indicators for the upflow zone, (i.e. the zone above the geothermal reservoir). Of note, $\mathrm{As}$ and $\mathrm{Hg}$ can also cause significant environmental problems in geothermal systems. This study investigated the concentrations of As and $\mathrm{Hg}$ of thermal waters and deposits around thermal springs in several active geothermal systems. The study findings can be used to estimate the natural amounts of As and $\mathrm{Hg}$ in fossil geothermal systems, which are similar to epithermal systems.

\footnotetext{
* Corresponding author
} 


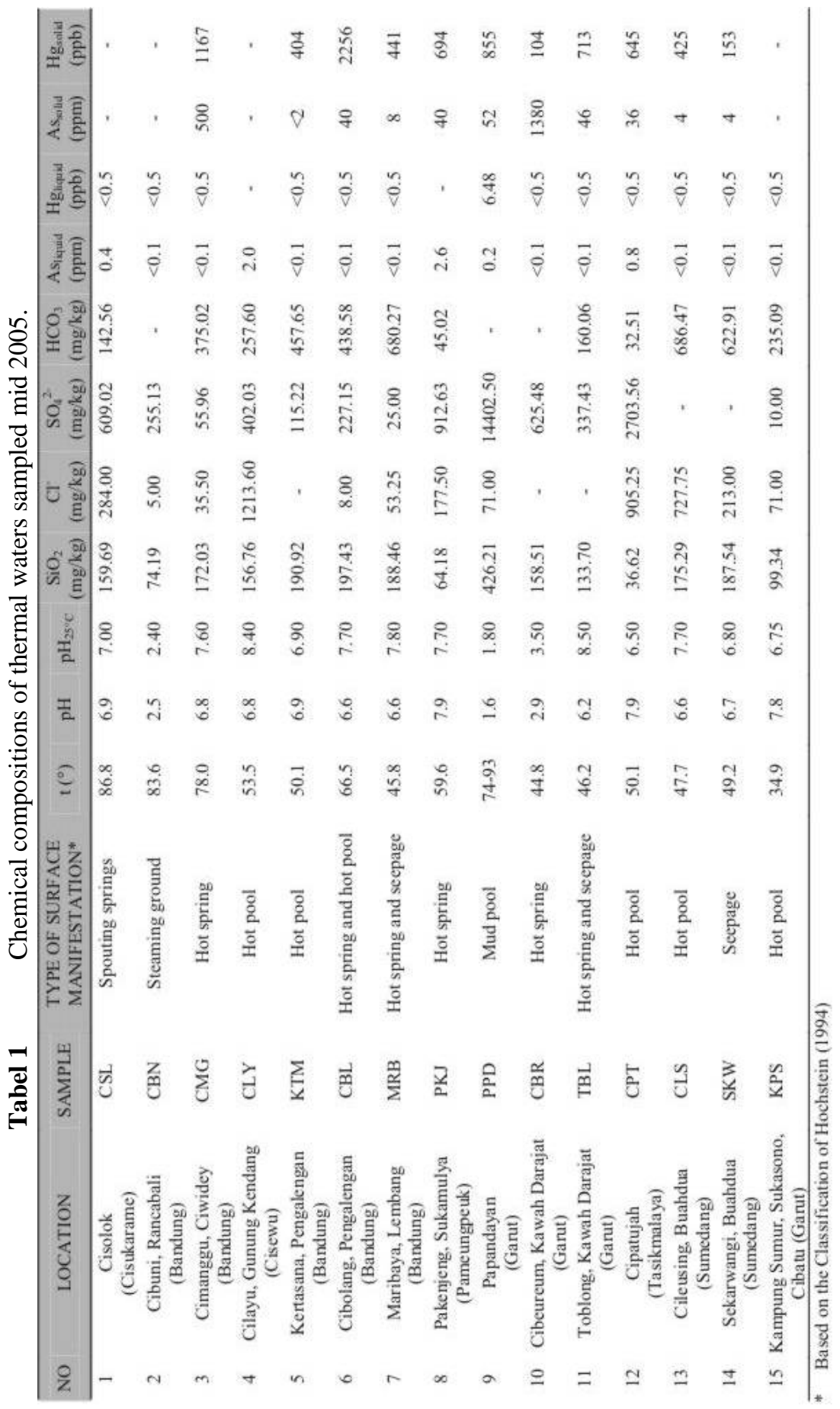


Groundwater and surface waters of epithermal-gold mining areas are often contaminated with As and Hg, e.g. Buyat, North Sulawesi. However, it is still unknown whether the contaminants are from the mining practices or due to natural conditions, where alteration minerals contain As and $\mathrm{Hg}$, or because of both reasons. The surface waters in geothermal systems are contaminated in a similar way due to thermal water activities in the bottom of rivers (e.g. [1]).

In geothermal systems, As occurs in thermal fluids as a result of rock dissolution. [2] reported that the concentration of As in several hot springs in geothermal fields ranges from less than 0.1 to $10 \mathrm{ppm}$; in Tongonan, Philippines and Los Azures, Mexico, the dissolved As in thermal waters can be more than $20 \mathrm{ppm}$. A high content of As is strongly influenced by the type of rocks interacting with the thermal fluids and the occurrence of rock alterations. [3, 4] concluded that unaltered andesite can dissolve $1.3 \mathrm{ppm}$ As into thermal waters; in contrast, basalt will not dissolve As into thermal waters, as indicated by the thermal waters from Iceland and Hawaii that have very low As concentrations, i.e. less than $0.01 \mathrm{ppm}[2]$.

Arsenic (As) is also present in rocks or deposits of hydrothermal alterations. [5] found that drilling cores from $1.5 \mathrm{~km}$ depth in the Broadland-Ohaaki geothermal system contain 1.2 to $1.9 \mathrm{ppm}$ As, whereas its near surface rock alteration contains 19 to $22 \mathrm{ppm}$ As. The surface precipitations of amorphous silica sinter, which are deposited from chloride type thermal waters in the Champagne Pool, New Zealand and the Steamboat Spring, USA, contain up to 2 wt.\% As, and are associated with significant Hg, Sb, Tl, Au and Ag [6 and 7].

Mercury (Hg) occurs in geothermal systems due to the absorption of vapor and volcanic gasses into thermal waters. On the surface, $\mathrm{Hg}$ is present as upflow. In association with $\mathrm{CO}_{2}$ and $\mathrm{H}_{2} \mathrm{~S}, \mathrm{Hg}$ can concentrate in soils. The Darajat geothermal field in West Java, Indonesia is a vapor dominated geothermal system; its soil in the upflow zone contains more than 125 ppb $\mathrm{Hg}$ [8]. In liquid dominated geothermal systems, the concentration of $\mathrm{Hg}$ in soils is lower.

An epithermal system is known as a fossil geothermal system. The occurrence of both epithermal and geothermal systems is influenced by the interaction between hot fluids and surrounding rocks. Previous study revealed that active geothermal systems have style and characteristics of alteration and/or mineralization similar to epithermal systems (e.g. [9] and [10]). In both systems, As and $\mathrm{Hg}$ occur as contaminants associated with antimony (Sb), boron (B), lithium (Li), fluoride $(\mathrm{F})$ and hydrogen sulfide $\left(\mathrm{H}_{2} \mathrm{~S}\right)$ [11]. In geothermal systems, As and $\mathrm{Hg}$ dissolve in thermal fluids and concentrate in surface alterations (e.g. [2] and [5]). Several previous studies have shown a relationship between As and $\mathrm{Hg}$ concentrations of thermal waters and the type of thermal fluids, especially chloride $(\mathrm{Cl})$ waters originating from a deep geothermal 
reservoir [e.g. 12]. Some detailed research on the relationship between chloride and As in geothermal areas was carried out in Taupo Volcanic Zone, New Zealand by [12] and in Yellowstone National Park by [13].

\section{$2 \quad$ Location and Methodology}

To understand the natural contents of As and $\mathrm{Hg}$ and their controlling factors in epithermal systems, fifteen (15) samples of thermal waters discharging as hot springs, hot pools, seepage and fumaroles were taken. Surface deposits around the thermal surface expressions were also sampled. The study area, West Java, has a lot of geothermal surface manifestations, such as hot springs, hot pools, fumaroles, mud pools and steaming ground. Figure 1 shows the sample locations and Table 1 lists the names and characteristics of the surface manifestations. The samples were taken from six hot springs, five hot pools, one spouting spring at Cisolok (CSL), one seepage at Sekarwangi (SKW), one mud pool at Gunung Papandayan (PPD) and one steaming ground at Cibuni (CBN).

The thermal water samples were collected into polypropylene bottles. Filtration through $0.45 \mu \mathrm{m}$ membrane filters was done, but acidification was unnecessary. The temperature and $\mathrm{pH}$ of the thermal waters were measured directly in the field. The samples were then analyzed in laboratory using Atomic Absorption Spectrophotometer (AAS). Sediment samples were analyzed using the Inductively Coupled Plasma (ICP) for As and the Cold Vapor method for Hg. Both water and sediment sampling techniques are described in detail in Nicholson [14].

\section{Chemical Compositions of Thermal Waters}

Table 1 shows the chemical compositions of the thermal fluids. The chloride (Cl) concentration of thermal waters is up to $1000 \mathrm{mg} / \mathrm{kg}$, but the thermal water of CLY contains more than $1,200 \mathrm{mg} / \mathrm{kg} \mathrm{Cl}$. The sulfate $\left(\mathrm{SO}_{4}\right)$ concentration is up to $3,000 \mathrm{mg} / \mathrm{kg}$, except in PPD where the $\mathrm{SO}_{4}$ content exceeds 14,000 $\mathrm{mg} / \mathrm{kg}$. The thermal waters sampled also contain up to $700 \mathrm{mg} / \mathrm{kg}$ bicarbonate $\left(\mathrm{HCO}_{3}\right)$.

The relative concentrations of $\mathrm{Cl}, \mathrm{SO}_{4}$ and $\mathrm{HCO}_{3}$ of thermal waters are given in Figure 2. Generally, the locations had either $\mathrm{HCO}_{3}$ water with $\mathrm{pH}$ of neutral to slightly basic (e.g. CMG, MRB, KTM) or $\mathrm{SO}_{4}$ acidic waters (e.g. steaming 


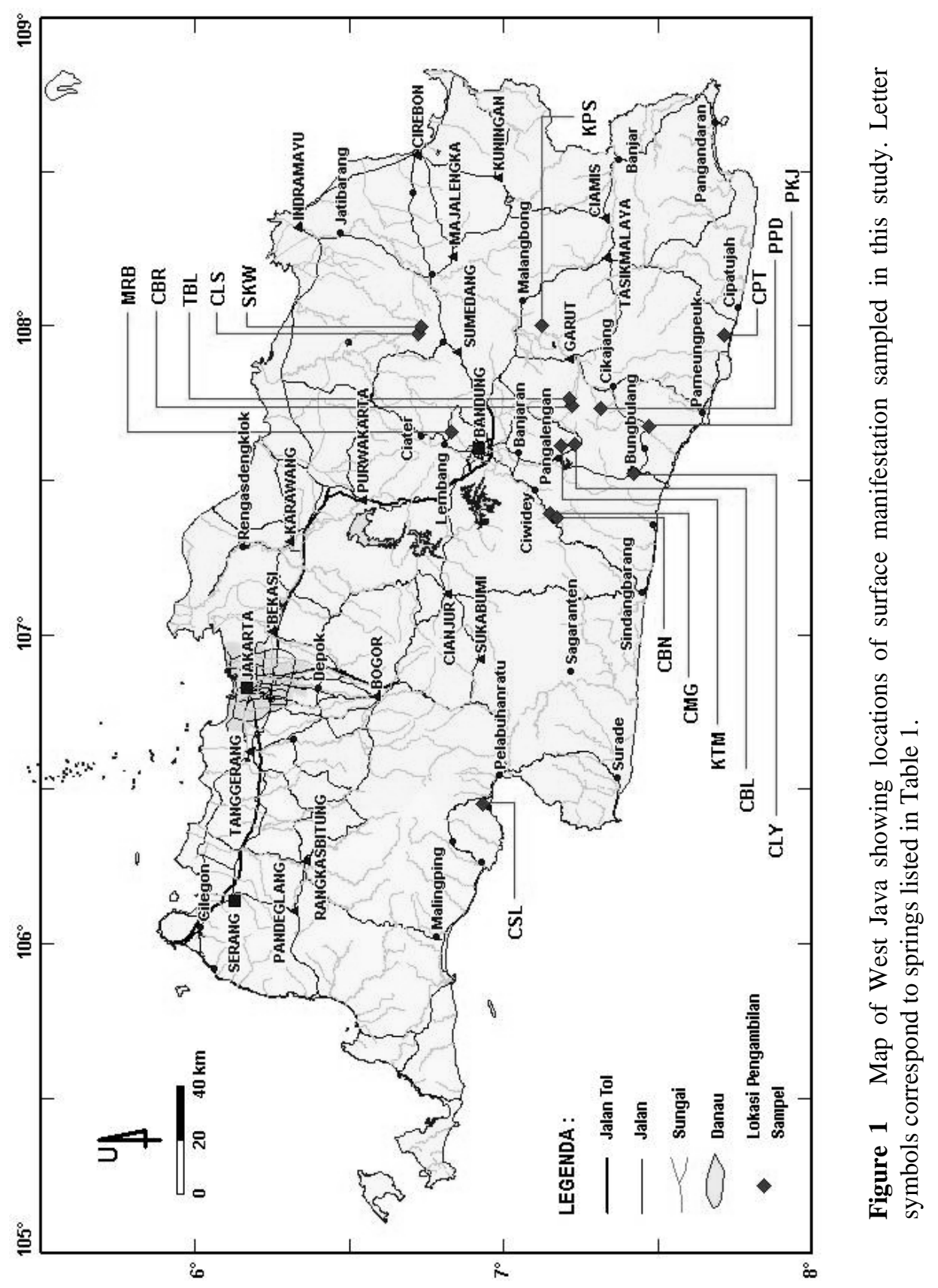


ground of CBN, CBR and mud pool of PPD). Mixing between $\mathrm{SO}_{4}$ and $\mathrm{HCO}_{3}$ waters occurs in TBL and CBL. Of the 15 samples, only the thermal water of CLY is mature chloride water. The thermal waters of PKJ and CLS are mixed chloride and $\mathrm{SO}_{4}$ waters and that of CLS and SKW are mixed chloride and $\mathrm{HCO}_{3}$ waters.

The thermal waters also contain between 130 and $200 \mathrm{mg} / \mathrm{kg}$ silica $\left(\mathrm{SiO}_{2}\right)$, except the waters of KPS, CPT, PKJ and CBN, which contain less than 100 $\mathrm{mg} / \mathrm{kg} \mathrm{SiO}_{2}$. The thermal fluids from PPD and CBR are acidic, and the dissolution of surrounding rocks causes these thermal waters to be silica rich.

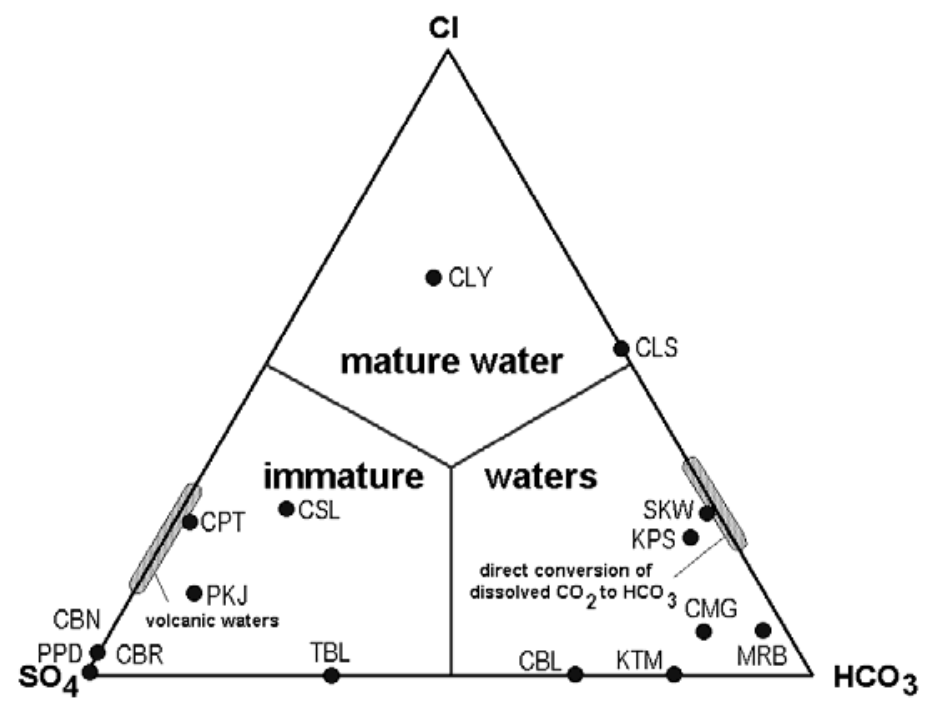

Figure 2 Relative concentrations of $\mathrm{Cl}, \mathrm{SO}_{4}$ and $\mathrm{HCO}_{3}$ showing the type of thermal waters. Mature water is chloride $(\mathrm{Cl})$ water, whereas immature waters are sulfate $\left(\mathrm{SO}_{4}\right)$ and bicarbonate $\left(\mathrm{HCO}_{3}\right)$ waters. Letter symbols correspond to the thermal springs listed in Table 1.

\section{$4 \quad$ Arsenic and Mercury Concentrations in Thermal Springs and in Deposits around Thermal Springs}

As shown in Table 1, the concentrations of As and $\mathrm{Hg}$ of thermal waters are mostly less than the detection limits of $0.1 \mathrm{ppm}$ and $0.5 \mathrm{ppb}$ respectively. However, the thermal waters from CLY, PKJ and CPT contain up to $2.6 \mathrm{ppm}$ As and the water of PPD contains $6.5 \mathrm{ppb} \mathrm{Hg}$. The concentration of As is not closely related to the $\mathrm{Hg}$ content of thermal waters. 
Surface alteration deposits occurring around the discharges of thermal waters contain up to $52 \mathrm{ppm}$ As and from 104 to $855 \mathrm{ppb} \mathrm{Hg}$. Arsenic (As) anomalies occur in CBR and in CMG, where As is as high as $1380 \mathrm{ppm}$ and $500 \mathrm{ppm}$, respectively. The surface deposits in CMG and CBL contain very high $\mathrm{Hg}$, i.e. about 1,200 and 2,400 ppb respectively. Even though the As and Hg contents of the surface deposits around the thermal springs vary, the concentration of As seems to correlate with the $\mathrm{Hg}$ content, i.e. the higher the As content of the surface deposit, the higher the $\mathrm{Hg}$ concentration (Figure 3). However, this correlation is only shown when the Hg concentration is below 1,000 ppb Hg. Above a concentration of $\mathrm{Hg} 1,000 \mathrm{ppb}$, the concentrations of As and $\mathrm{Hg}$ are independent.

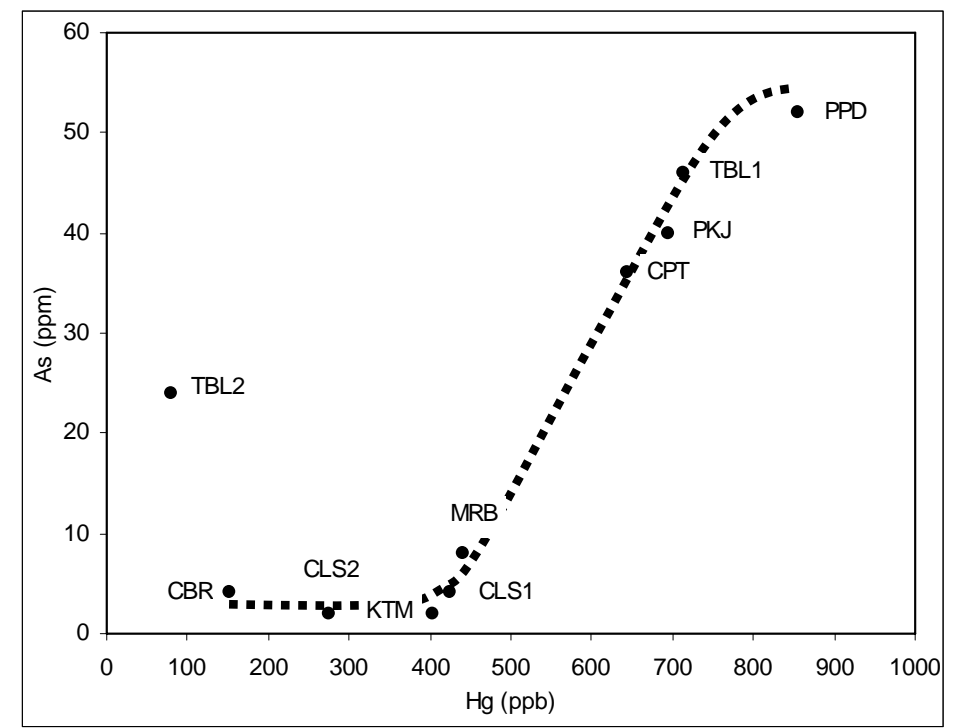

Figure 3 Correlation between As and Hg contents in sediment and/or deposit around thermal spring. Below a concentration of 1,000 ppb Hg, As content increases exponentially with an increase in $\mathrm{Hg}$ content. Above that, concentrations of As and $\mathrm{Hg}$ are independent. Letter symbols correspond to the springs listed in Table 1.

\section{$5 \quad$ Type of Thermal Water vs. the Arsenic and Mercury Contents}

Figure 4 shows that the As content in thermal waters increases with an increase in the concentration of chloride. This confirms that As is carried by the chloride type thermal water. A similar correlation is not shown by the $\mathrm{Hg}$ and chloride 
contents of thermal waters, perhaps because in this study, the Hg content of most samples is below the detection limit of analysis, i.e. below $0.5 \mathrm{ppb}$.

Deep reservoir fluids are dominated by chloride, whereas steam condensate waters occurring near the surface are either $\mathrm{SO}_{4}$ or $\mathrm{HCO}_{3}$ rich and are low in chloride content. Figure 5 shows a correlation between the $\mathrm{SO}_{4}$, As and $\mathrm{Hg}$ of thermal waters. In contrast to the correlation with the chloride content shown in Figure 4, the As and $\mathrm{Hg}$ contents of thermal waters tend to decrease with an increase in the concentration of $\mathrm{SO}_{4}$. However, some samples did not conform to the trend line, such as the thermal water of PKJ, which contains high As content as a result of intense interaction between the thermal fluids and surrounding rocks. The thermal water from PPD has very high Hg content, possibly due to the effects of volcanic gasses and vapor that is commonly present in a volcanic area.

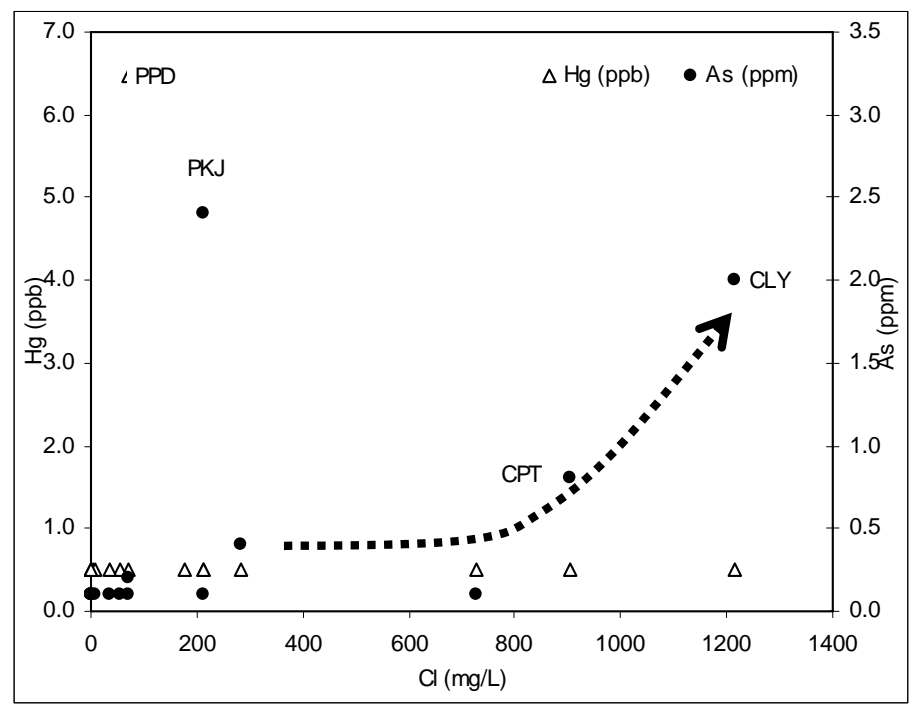

Figure 4 Correlation between chloride, As and Hg contents in thermal fluids. Triangular symbol is $\mathrm{Hg}$ content and filled circle is As content. Concentrations of As and $\mathrm{Hg}$ are usually below the detection limit, except in the thermal waters of PPD, PKJ, CPT and CLY. Generally, the higher the chloride content, the higher the concentration of As. The correlation between chloride and $\mathrm{Hg}$ contents is unclear. Letter symbols correspond to the thermal springs listed in Table 1.

Figure 6 shows the correlation between the chloride content of thermal waters and the As and $\mathrm{Hg}$ contents of surface deposits around thermal water discharges. It shows that an increase in the chloride content of thermal waters 
up to $400 \mathrm{mg} / \mathrm{kg}$ is associated with a sharp decrease in both As and Hg contents of surface deposits. This negative correlation is seen in the surface manifestations in CBR, CBL, CMG, PKJ and SKW. Furthermore, if the concentration of chloride in thermal waters is more than $400 \mathrm{mg} / \mathrm{kg}$, the correlation is positive, i.e. increasing chloride content corresponds to increases in concentrations of As and $\mathrm{Hg}$ in surface deposits. The surface manifestations in CLS and CPT show this correlation.

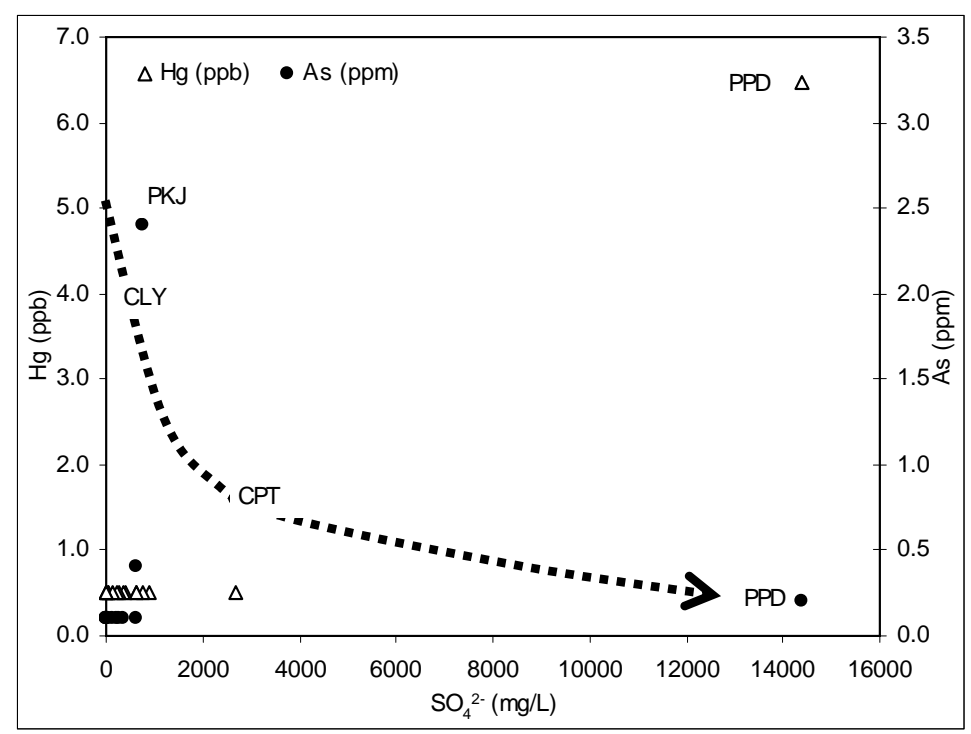

Figure 5 Correlation between $\mathrm{SO}_{4}$, As and $\mathrm{Hg}$ contents in thermal fluids. Triangular symbol is $\mathrm{Hg}$ content and filled circle is As content. Generally, the higher the $\mathrm{SO}_{4}$ content, the lower the concentration of As. The correlation between $\mathrm{SO}_{4}$ and $\mathrm{Hg}$ contents is unclear. Letter symbols correspond to the thermal springs listed in Table 1.

\section{Discussion}

In most geothermal systems, deep reservoir fluids are undersaturated with respect to arsenopyrite and other As-bearing minerals [15]. Thus, As tends to dissolve into reservoir fluids rather than precipitating and forming As-bearing deposits. [16] reported that the reservoir fluids of the Yellowstone geothermal system contain about $400 \mathrm{ppm}$ As. Furthermore, as the reservoir fluids rise to the surface and boil, As is conserved in the liquid phase (as is the case of other conservative elements such as chloride and silica). Conserquently, the concentration of As of thermal waters increases. In contrast, mixing between 

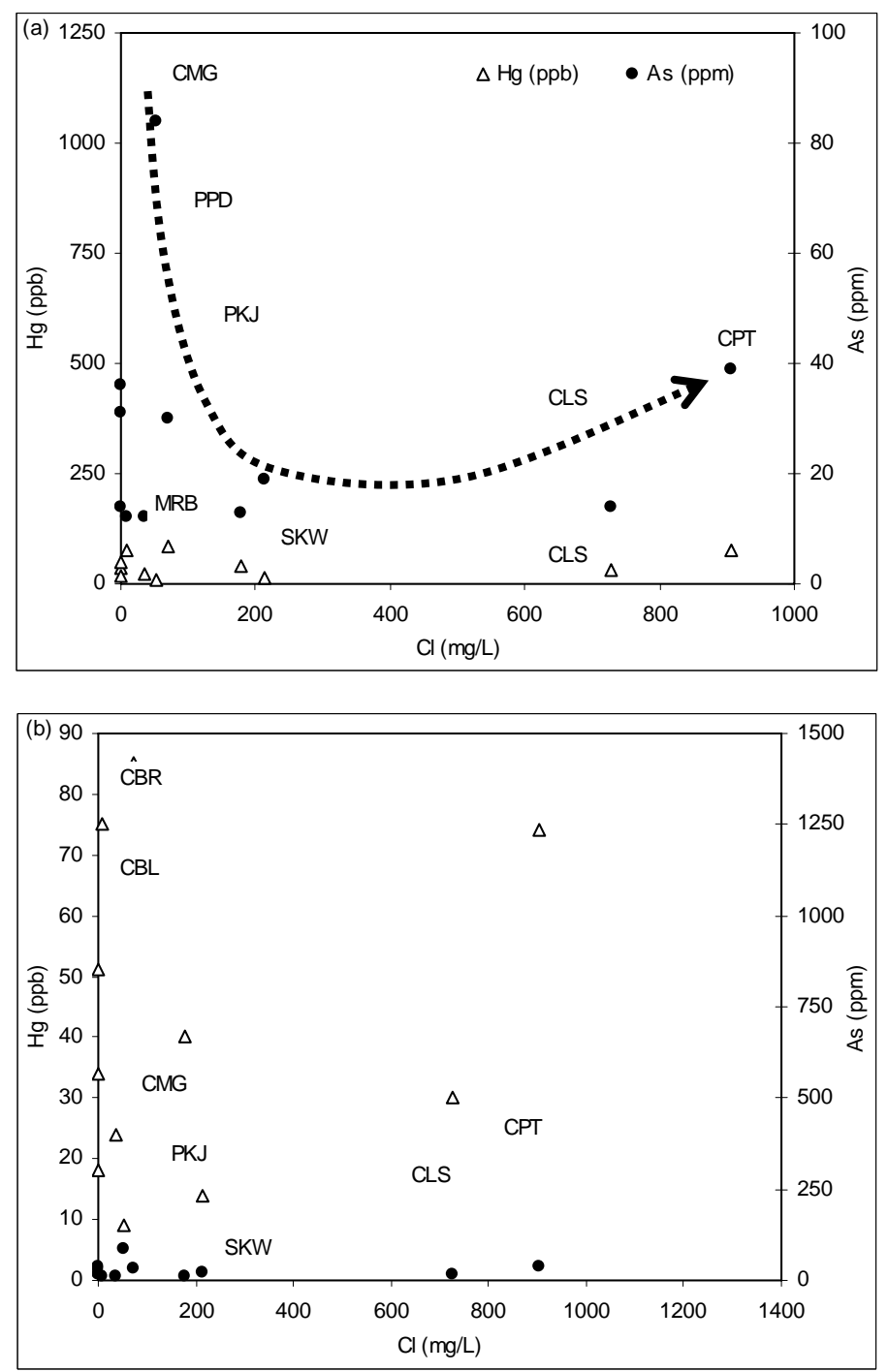

Figure 6 Correlation between concentration of chloride in thermal waters and As and $\mathrm{Hg}$ contents in deposit around hot springs. Triangular symbol is $\mathrm{Hg}$ content and filled circle is As content. Figure (b) is a part of Figure (a) showing low concentrations of chloride, Hg and As. The correlation between chloride, As and $\mathrm{Hg}$ is shown as a trend line in Figure (a). Letter symbols correspond to the thermal springs listed in Table 1. 
reservoir fluids and groundwater or surface water or steam heated waters $\left(\mathrm{SO}_{4}\right.$ or $\mathrm{HCO}_{3}$ waters) can cause the As content of thermal waters to decrease. Therefore, it is clear that the change in the As content of thermal waters corresponds to the changes in the type of thermal fluids and fluid processes. Figure 6a shows that chloride type waters will contain a high amount of As, whereas $\mathrm{SO}_{4}$ and $\mathrm{HCO}_{3}$ waters will contain a low amount of As. Boiling can then increase the amount of chloride of thermal waters, whereas mixing will reduce the amount of chloride, but increase $\mathrm{SO}_{4}, \mathrm{HCO}_{3}$ and $\mathrm{Mg}$ contents of thermal fluids. It is concluded that the As content of thermal fluids will increase due to boiling, but will decrease because of dilution by other fluids. This conclusion is supported by [12], which showed a positive correlation between chloride and As contents of thermal fluids, especially chloride water related to a geothermal reservoir.

This study shows that As and Hg are dominant in the chloride type waters; it also shows that the As and $\mathrm{Hg}$ contents in the thermal fluids exponentially increase with an increase in the concentration of chloride of fluids. In contrast, the As and $\mathrm{Hg}$ contents decrease with an increase in the $\mathrm{SO}_{4}$ content of fluids. An increase in the chloride content usually corresponds to an increase in the saturation of silica $\left(\mathrm{SiO}_{2}\right)$, therefore the thermal water can form silica sinter on the surface when chloride type thermal water is quickly cooled. However, the relationship between chloride, As and $\mathrm{Hg}$ contents of the thermal waters in this study is still unclear because there were few chloride water samples; most samples were from $\mathrm{SO}_{4}$ and $\mathrm{HCO}_{3}$ waters. Strauffer and Thompson [17] concluded that the correlation of As and $\mathrm{Hg}$ contents with respect to chloride content of thermal fluids is also influenced by dissolved $\mathrm{H}_{2} \mathrm{~S}$ and $\mathrm{CO}_{2}$ in thermal fluids; these dissolved compounds can react, forming $\mathrm{SO}_{4}$ and $\mathrm{HCO}_{3}$ waters at near surface conditions.

At depth, arsenic (As) rich thermal fluids will form oxy-anion, especially with carbonate ions; these fluids can also quickly react with the surrounding rocks [17]. As the fluids rise to the surface, the fluids boil and form the liquid and vapor phases. The fluids will be saturated with respect to As, whereas the vapor will be saturated with Hg. Furthermore, the thermal fluids, which are saturated with respect to As and $\mathrm{Hg}$, discharge as surface manifestations, i.e. as hot springs, hot pools, mud pools, steaming ground and fumaroles. Arsenic (As) can precipitate as As bearing surface deposits occurring around the manifestations. $\mathrm{Hg}$ associated with vapor can be adsorbed into soil and surface alteration. The mud pool of Papandayan (PPD) is an example where a high content of $\mathrm{Hg}$ is carried by vapor and adsorbed into a geothermal surface manifestation.

Realgar (AsS), cinnabar (HgS) and stibnite $\left(\mathrm{Sb}_{2} \mathrm{~S}_{3}\right)$ are very common minerals associated with the surface alteration of silica sinter. Arsenopyrite (FeAsS) is 
also a common As bearing mineral usually present at depth. Orpiment $\left(\mathrm{As}_{2} \mathrm{~S}_{3}\right)$ can form near surface manifestations of sulfate waters [18]. Realgar is more stable than orpiment in hot temperature environments, but orpiment is more stable compared to realgar at low $\mathrm{pH}$ condition [19]. In low temperature geothermal systems, native As is commonly present, such as at Osorezan, Japan [20]. However, both As and $\mathrm{Hg}$ can be readily adsorbed onto clay, organic matter and hydrous oxides. Surface deposits containing As in association with $\mathrm{Hg}$, antimony (Sb), thallium ( $\mathrm{Tl})$, gold $(\mathrm{Au})$ and silver (Ag) are commonly orange (e.g. the Champagne Pool, Waiotapu in New Zealand; Steamboat Spring in Colorado; and Roosevelt Hot Spring in Utah), even though color is not an indicator for the presence of As. The surface deposits at CMG and CBR are orange and contain 500 and 1,380 ppm As respectively. The deposits at CLS, SKW and MRB are also orange, but only contain up to 8 ppm As.

\section{$7 \quad$ Conclusions}

This study in several geothermal systems in West Java, Indonesia shows that most of thermal fluids contain low concentrations of As and Hg, but some may contain up to $2.6 \mathrm{ppm}$ As and $6.5 \mathrm{ppb} \mathrm{Hg}$. The concentrations of As and $\mathrm{Hg}$ in surface deposits around the thermal discharges (e.g., at hot springs, hot pools, mud pools, fumaroles and steaming ground) are often up to $50 \mathrm{ppm}$ and $800 \mathrm{ppb}$ respectively. However, the concentrations of As and $\mathrm{Hg}$ can be much higher. If an epithermal system is a fossil geothermal system, its hydrothermal alteration may contain As and $\mathrm{Hg}$ in amounts as high as that in the active geothermal system.

The (natural) contents of As and Hg in epithermal and geothermal systems are influenced by the type of host rocks that interact with the hydrothermal fluids; andesites will dissolve more As and $\mathrm{Hg}$ into thermal fluids compared to basalts. The concentrations of As and $\mathrm{Hg}$ in thermal fluids and in surface alterations can also be influenced when thermal fluids undergo boiling and mixing processes. Other effects influencing the amount of As and $\mathrm{Hg}$ are the presence of volcanic gasses and near surface oxidation. All effects in epithermal systems can be understood by a study of alteration and mineralization.

However, the exponential correlation between chloride, As and Hg shown in this study needs to be confirmed through further study, especially on the chloride type thermal waters. It is also recommended to study one particular geothermal system, so effects of boiling, mixing and volcanic gasses can be understood. Dissolved As and $\mathrm{Hg}$ species in thermal waters, as well as organism effects, need to be investigated, as different chemical species can have very different impacts on the environments. 


\section{Acknowledgement}

This research was funded by the ITB Research Grant No. 0076/K01.03/PL.1.5/VI/2005. The sample preparation is by Andi Mardianza, Tri Yulinawati and Ari Surjoko, and the chemical analysis is by Mulyana Sukandar.

\section{References}

[1] Webster, J.G., The Source of Arsenic (and Other Elements) in the Marbel-Matingao River Catchment, Mindanao, Philippines, Geothermics, 28, 95-111, 1999.

[2] Webster, J.G. \& Nordstrom, D.K., Geothermal Arsenic, In A.H. Welch and K.G. Stollenwerk (eds.), Arsenic in Ground Water, Kluwer Academic Publisher, USA, pp.101-125, 2003.

[3] Ellis, A.J. \& Mahon, W.A., Natural Hydrothermal Systems and Experiment Hot Water/rock Interactions, Geochimica et Cosmochimica Acta, 28, 1323-1357, 1964.

[4] Ellis, A.J. \& Mahon, W.A., Natural Hydrothermal Systems and Experiment Hot Water/Rock Interactions (part II), Geochimica et Cosmochimica Acta, 31, 519-538, 1967.

[5] Simmons, S.F. \& Browne, P.R.L., Hydrothermal Minerals and Precious Metals in the Broadland-Ohaaki Geothermal Systems: Implications for Understanding Low-Sulfidation Epithermal Environments, Economic Geology, 95, pp.971-999, 2000.

[6] White, D.E., Mercury and Base-Metal Deposits with Associated Thermal and Mineral Waters. in H. Barnes (ed.), Geochemistry of Hydrothermal Ore Deposits, New York, Holt, Rinehart, and Winston, pp.575-631, 1967.

[7] Weissberg, B.G., Gold-Silver Ore-Grade Precipitates from New Zealand Thermal Waters, Economic Geology, 64, 95-108, 1969.

[8] Amoseas Indonesia Inc., Geothermal Assessment of the Darajat Contract Area, West Java, Indonesia, Phase I, Report, Amoseas Indonesia Inc., Indonesia, 124p, 1987.

[9] Hedenquist, J.W., Mineralization Associated with Volcanic-Related Hydrothermal Systems in The Circum-Pacific Basin, in M.K. Horn (ed.), Trans Fourth Circum-Pacific Energy and Mineral Resources Conference, Singapore, pp. 513-524, 1987.

[10] White, D.E., Active Geothermal System and Hydrothermal Ore Deposits, Economic Geology, 75th Anniversary Volume, pp.392-423, 1981.

[11] Webster-Brown, J.G., Chemical Contaminants and Their Effects, in Environmental Safety and Health Issues in Geothermal Development, in World Geothermal Congress, Kazuno, Japan, 2000. 
[12] Ritchie, J.A., Arsenic and Antimony in Some New Zealand Thermal Waters, New Zealand Journal of Science, 4, 218-229, 1961.

[13] Nordstrom, D.K, Ball, J.W. \& McCleskey, R.B., Processes Governing Arsenic Concentrations on Thermal Waters of Yellowstone National Park, in U.S. Geological Survey workshop on Arsenic in the environment, 2001.

[14] Nicholson, K., Geothermal Fluids, Chemistry and exploration techniques. Springer-Verlag Berlin Heidelberg, 63 p, 1993.

[15] Ballantyne, J.M. \& Moore, J.N., Arsenic Geochemistry in Geothermal Systems, Geochimica et Cosmochimica Acta, 52, pp.475-483, 1988.

[16] Fournier, R.O., Thompson, J.M. \& Hutchison, R.A., Fluctuations in composition of Cistern Spring, Norris Geyser Basin, Yellowstone National Park, Wyoming - variable boiling and mixing 1962-1985, in Proceeding 5th Water-Rock Interaction Symposium, Reykjavik, Iceland, pp.206-209, 1986.

[17] Strauffer, R.E. \& Thompson, J.M., Arsenic and Antimony in Geothermal Waters of Yellowstone National Park, Wyoming, USA, Geochimica et Cosmochimica Acta, 48, pp.2247-2561, 1984.

[18] Spycher, N.F. \& Reed, H.M., As(III) and Sb(III) Sulfide Complexes: An Evaluation of Stoichimetry and Stability from Existing Experimental Data, Geochimica et Cosmochimica Acta, 53, pp.2185-2194, 1989.

[19] Nordstrom, D.K. \& Archer, D.G., Arsenic Thermodynamic Data and Environmental Geochemistry, in A.H. Welch and K.G. Stollenwerk (eds.), Arsenic in ground water. Kluwer Academic Publisher, USA, pp.125, 2003.

[20] Sergeyeva, E.I., Khodakovskiy, I.L., \& Vernadskiy, V.I., Physiochemical Conditions of Formation of Native Arsenic in Hydrothermal Deposits, Geochemistry International, 6, pp.681-694, 1969. 